\title{
EVALUATION OF THE 100 MOST CITED ARTICLES ON BEHCET'S DISEASE: A BIBLIOMETRIC ANALYSIS
}

\author{
Erkan Ozduran ${ }^{1}$, Volkan Hanci \\ ${ }^{1}$ Dokuz Eylul University, Physical Medicine and Rehabilitation, Algology, Izmir, Turkey \\ 2 Dokuz Eylul University, Anesthesiology and Reanimation, Izmir, Turkey
}

Corresponding Author: Erkan Ozduran, MD, E-mail: erkanozduran@gmail.com

Received: 03.10.2021; Accepted: 11.01.2022; Available Online Date: 27.01.2022

(C) Copyright 2021 by Dokuz Eylül University, Institute of Health Sciences - Available online at https://dergipark.org.tr/en/pub/jbachs

Cite this article as: Ozduran E, Hanci V. Evaluation of the 100 Most Cited Articles on Behcet's Disease: A Bibliometric Analysis. J Basic Clin Health Sci 2022; 6: 247-259.

\begin{abstract}
Purpose: Bibliometric studies examine the accumulated scientific data on a specific subject and evaluate its scientific performance. Our study aimed to evaluate the 100 most cited publications related to Behcet's Disease regarding their bibliometric properties.

Methods: Our study was conducted using the "Web of Science (WOS) "search engine. The search was done on 01.06.2021, and the top 100 most cited publications were determined. In addition, the total number of citations of each publication, the annual number of citations, the authors and the information of the study were determined.

Results: In the literature analysis between 1975 and 2021, it was determined that there were a total of 13280 publications related to Behcet's Disease. The total citation average of the 100 most cited articles was $256.35 \pm 311.53$, annual citation average of $13.31 \pm 13.41$ was detected. The first area that these studies focused on were treatment (26\%). A significant relationship was found between the year of publication of the article, the $Q$ index of the journal and the class of the journal, and the number of annual citations. In addition, a significant relationship was found between the subject of the study and the presence of a group of authors in the study and both the total number of citations and the average annual citation count $(p<0.05)$.

Conclusion: Our study is the first to evaluate and analyse the top 100 most cited studies on Behcet's Disease in the literature. Today, the importance of rheumatological diseases in the clinic is increasing day by day; Behcet's disease, which is among these diseases, has a great place.
\end{abstract}

Keywords: Behcet syndrome, rheumatology, biblometric

\section{INTRODUCTION}

It is possible to find various publications in different clinical and surgical branches both at home and abroad to identify the most cited articles in various branches of medicine (1-4). When a scientific article cites another scientific article as a source, it is expressed as a reference to that article. The amount of citations of scientific articles indicates the effectiveness of that article. Therefore, scientific articles with more references and journals with higher impact value are considered more qualified (2).
Garfield published the first bibliographic study in 1987 in "The Journal of the American Medical Association (JAMA)" with the title "The 100 most cited articles published in JAMA"(3). Since then, numerous articles have been reviewed and presented as "most cited articles" not only in general journals but also in specific journals (4,5). Between 1990 and 2020, Bagcier et al. (6) investigated the 100 most cited articles in fibromyalgia syndrome, while Kreutzer et al. (7) investigated the 100 most cited articles in neurorehabilitation between 2005 and 2016 . 


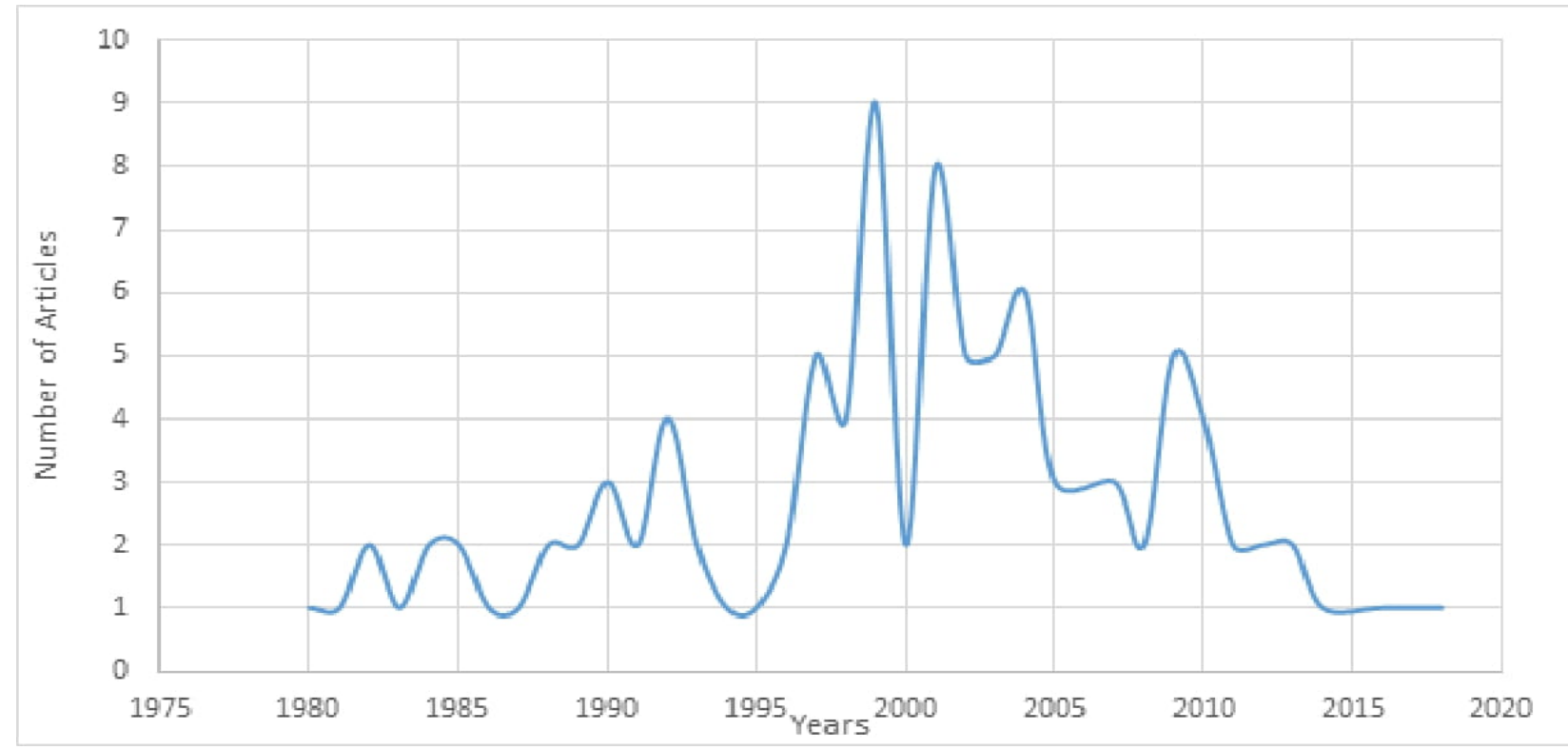

Figure 1. Distribution of the top 100 most cited articles on Behcet's Disease by years

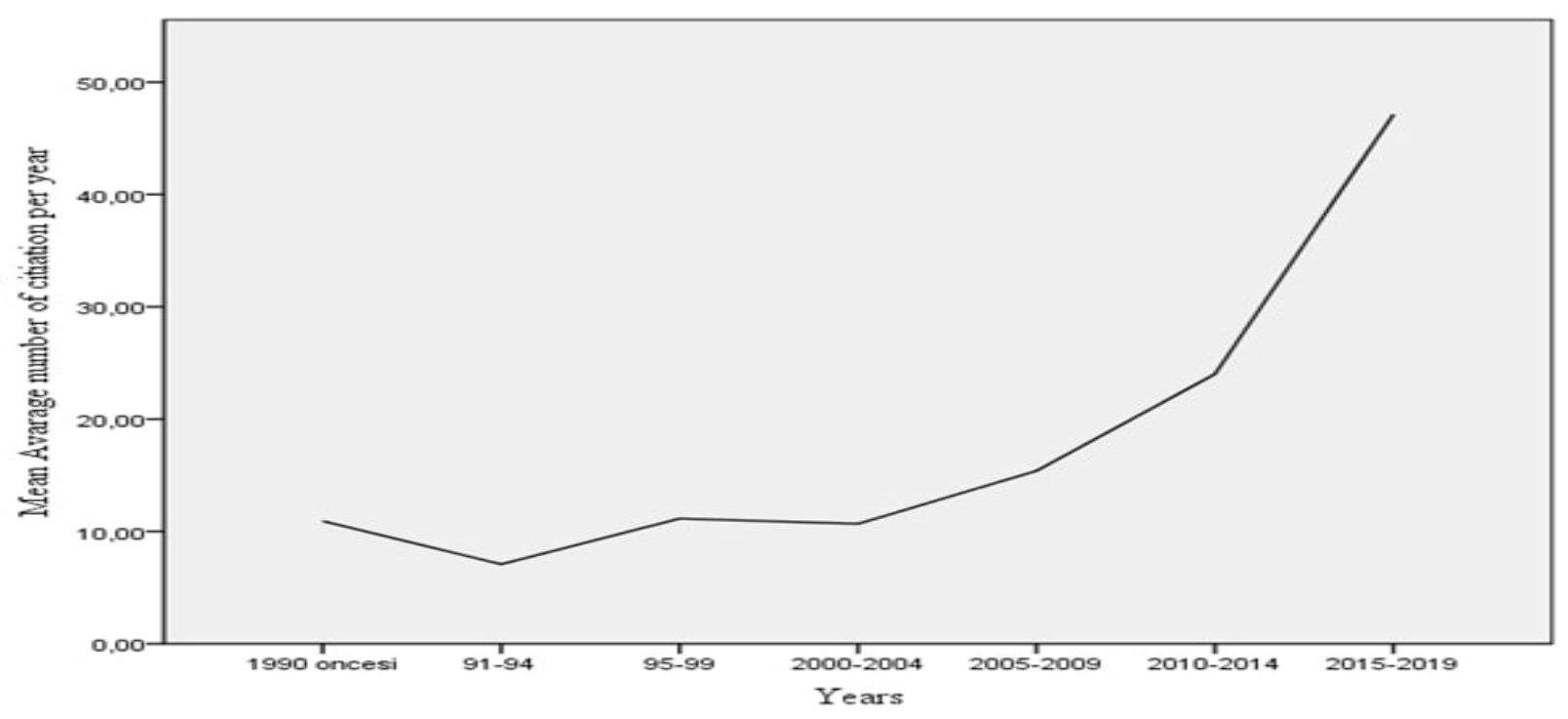

Figure 2. Change in the average number of annual citations by years

Behcet's Disease (BD) is a multisystem variable vascular vasculitis heterogeneous in terms of demographic characteristics, organ manifestations, severity of relapses, course of the disease, response to treatment, and prognosis among patients (8). Clinically, the disease presents in most patients with oral and genital ulcerations, papulopustular lesions, erythema nodosum-like lesions, and organ/system involvement, including uveitis, arterial and venous thrombosis, and aneurysms, nervous system involvement, and gastrointestinal tract involvement (8). The disease, seen in countries located on the Silk
Road, is seen in $20-420 / 100,000$ in Turkey, $80 / 100,000$ in Iran, and $0.64 / 100,000$ in the United Kingdom (9). Treatment often involves colchicine, topical steroids, azathioprine, systemic and topical steroids, and anti-TNF agents (10).

The importance and place of rheumatological diseases in the clinic are increasing day by day. The knowledge of $\mathrm{BD}$, one of the rheumatic diseases, by subsequent clinicians is essential because of the pain of following future studies and developments. Many studies have been carried out on BD in recent years. However, there are no bibliometric studies in which all 


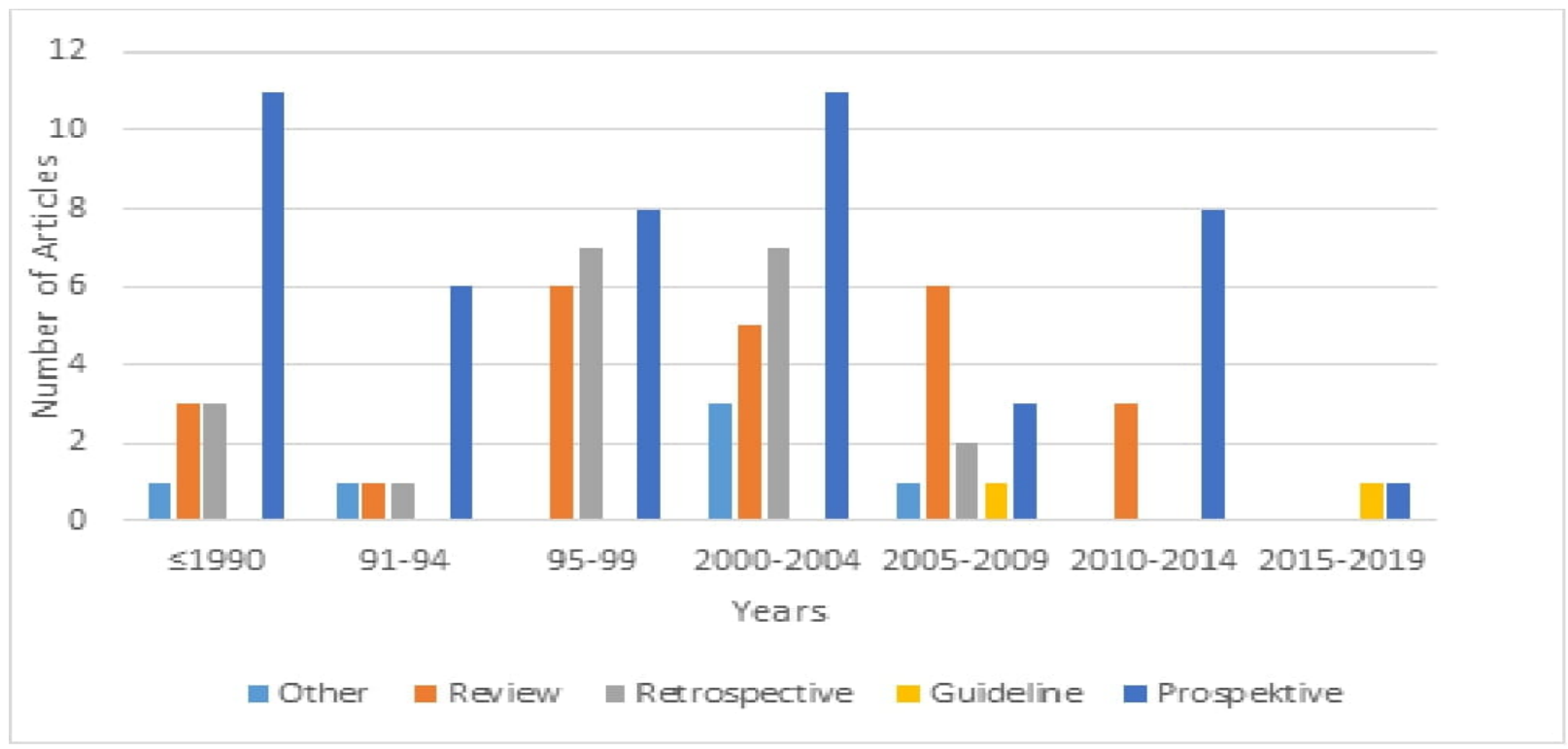

Figure 3. Distribution of the top 100 most cited article types on Behcet's Disease by years

of these studies are compiled. These efforts can be a guide in the BD area as well as in other areas. Our study aimed to examine the most cited internationally articles about BD by authors, countries, and institutions through the ISI and WOS search engine and to analyse bibliometrics in which journals they were published (11).

\section{MATERIAL AND METHODS}

In this study, which was planned as a cross-sectional study, the "advanced mode" feature of the ISI and WOS search engine was used after obtaining the consent of the ethics committee (Ethics Committee decision no: 6272-GOA 2021/16-31). Behcet Syndrome and its synonyms have been searched using MeSH (Medical Subject Headings 2021) Browser. As search key "TS=behc* AND TI=behc* OR TS=behç* AND TI=neuro-behc* OR TS=neurobehc $^{*}$ AND TI=neuro-behc* OR TS=neuro-behc* AND TI=neuro-behç * OR TS=vasculo-behc* AND $\mathrm{TI}=$ vasculo-behc* OR TS=vasculo-behc* AND $\mathrm{TI}=$ vasculo-behc*" was used. Articles were included from 1975 to June 2021. The search was conducted on 01.06 .2021 , and the 100 most cited internationally sourced articles on the subject were determined. A list was drawn up for the first 100 articles. Individual authors listed as names were scanned and checked to see if they were included in other articles on the list. The total number of citations of each publication, the number of citations per year, the study authors, the study, and the information of the journal were determined using WOS. Articles found to be due to writing and fact-reporting to the editor were not included in the study.

\section{Statistical Analysis}

Statistical analysis of the data obtained in the research was performed using SPSS (Statistical Package For Social Sciences, Chicago, IL, USA) 20.0 program. Student t-test, Kruskal Wallis test, Mann Whitney $U$ test, and square test were applied to compare the groups. The $p$ value below 0.05 was considered a significant difference.

\section{RESULTS}

From January 1975 to June 2021, it was determined that there were a total of 13280 publications in the WOS search engine. The most cited study had 3010 citations, while the lowest number of citations in the top 100 most cited studies was 133 . The distribution of the first-name authors of the 100 most cited articles in the BD field is stated in Table 1. The average number of citations of the 100 most cited studies was $256.35 \pm 311.53$. The annual citation numbers of the studies ranged from 94.06 to 3.40 and were found to average $13.31 \pm 13.41$.

The most cited study was "Criteria for diagnosis of Behcet's-Disease," published in the journal "Lancet" in 1990 by Silman AJ et al. The institution with the most articles on BD was Istanbul University with 32, followed by Mayo Clinic, St Marianna University with 4 articles (Table 2). Other features of the 100 most 


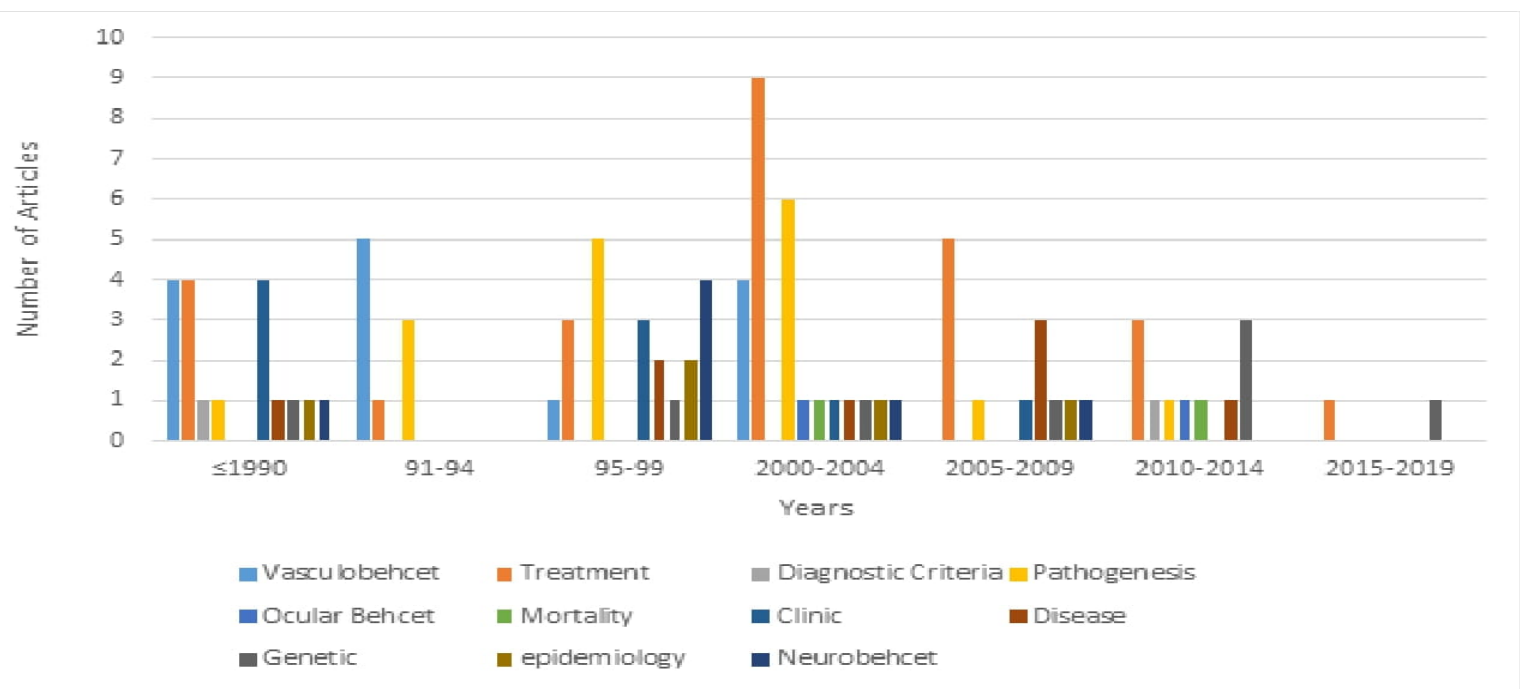

Figure 4. Distribution of the top 100 most cited article topics on Behcet's Disease by years

cited studies in the field of Behcet's Disease were reported in Table 3.

According to the results of our study, $26 \%$ of the BD articles were published between 2000 and 2004, followed by the studies between $1995-1999$ with $21 \%$ (Fig. 1). Furthermore, a weak positive correlation was found between the year of publication and the average number of citations per year (Table 4, Fig. 2). When the top 100 most cited studies on BD were examined, the top three areas were treatment $(26 \%)$, pathogenesis $(17 \%)$, and Vasculobehcet $(14 \%)$, respectively. (Table 3 ) It was determined that the average number of citations in both total and annual studies related to the diagnostic criteria was higher. Looking at the years, it was seen that studies on treatment and genetics were at the forefront with the 2010s, when studies in the field of disease pathogenesis attracted attention until the early 2010 s (Fig. 3). The names, years, authors and average annual citation numbers, and total citation numbers of the first 100 studies were reported in Table 5 .

The top three journals with the top 100 most cited publications are "Annals of the Rheumatıc Diseases" (9\%), "Journal of Rheumatology"(8\%), and "Arthritis and Rheumatism" $(8 \%)$ respectively (Table 3$)$. The distribution of articles in terms of $Q$ indexes was Q1 69\%, Q2 21\%, Q3 8\%, Q4 2\% (Table 3). It was found that the total and average annual citation numbers of publications published in journals with Q1 indexes were higher. The impact factors of the journals had a moderate positive correlation relationship between

Table 1. The first authors of the 100 most cited articles about Behcet's Disease in the literature

\begin{tabular}{|l|c|}
\hline First Authors Names & Number of cited articles \\
\hline Hamuryudan V, Sfikakis PP & 4 \\
\hline Gul Ahmet, Hatemi Gulen, Yazici H, Yurdakul S & 3 \\
\hline $\begin{array}{l}\text { Alpsoy E, Davatchi F, Evereklioglu C, Kotter I, Mizuki N, Ohno S, Tugal-Tutkun I, } \\
\text { Serdaroglu, P }\end{array}$ & 2 \\
\hline Akman-Demir G, Aktulga E, Al-Araji A, Arida A, Azizlerli G, BayraktarY, Benezra D, \\
Bhakta BB ,Calamia Kenneth T., Chambers JC, Chi Wei, de Chambrun Marc \\
Pineton, Dick Andrew D. ,Direskeneli H, Erkan F, Espinosa G, Frassanito MA, Geri \\
Guillaume,Ghate JV, Hamza M, Hamzaoui K Hasan A, Hassard PV, Kaklamani \\
VG,Kashara Y,Kidd D ,Kirino Y, Koc Y, Kocer N,Kone-Paut I, Kural-Seyahi E, \\
Kurokawa MS,Lakhanpal S, Lee KH, Lehner T, Lie JT, Mahr A, Masuda K, \\
Matsumoto T, Mege JL, Melikoglu M, Mendes D,Mizushima Y, Mogulkoc N, Niwa \\
Y,Nussenblatt RB, Oduffy JD, Ozyazgan Y,Park JH, Pervin K, Remmers Elaine F, \\
Saadoun D, Sakane T, Sayinalp N, Siva, A, Takeno M, Turan B, Tursen U, Tuzun H, \\
Verity DH, Wwchsler B, Zhou Q, Zouboulis CC \\
\hline
\end{tabular}


Table 2. The first authors of the 100 most cited articles about Behcet's Disease in the literature

\begin{tabular}{|l|c|}
\hline Institutions of the First Authors & Number of cited articles \\
\hline Istanbul University & 32 \\
\hline Mayo Clinic, St Marianna University & 4 \\
\hline $\begin{array}{l}\text { Hacettepe Unıv., National Institutes of Health, United Med \& Dent Sch, Guys \& } \\
\text { St Thomas Hosp, Univ. Athens }\end{array}$ & 3 \\
\hline $\begin{array}{l}\text { Akdeniz Univ, Hokkaıdo Unıv, Pitié-Salpêtrière University Hospital, Tübingen } \\
\text { Univ Hosp, Univ Tehran }\end{array}$ & \\
\hline $\begin{array}{l}\text { Beth Israel Hosp ,Bristol Eye Hosp, Cedars Sinai Med Ctr, Epe Ctr Hosp Vila } \\
\text { Nova Gaia Espinho, Erciyes Univ, Fac Med Tunıs, Free, Univ Berlin, Gaziantep } \\
\text { Univ, Grp Hosp Pıtıe Salpetriere, Hop Nord Marseille, Hosp Clin Barcelona, } \\
\text { Juntendo Unıv, Kınkı Unıv, Kochı Prefectual Hosp, Laikon Gen Hosp, Marmara } \\
\text { Univ, Med Univ Tunis, National Eye Institute, Royal Free Hosp, St Thomas } \\
\text { Hosp, Sun Yat Sen Univ, Tokaı Unı, Unıv Manchester, Unıv Tokyo, Unıv } \\
\text { Zurıch Hosp, Univ Bari, Univ Hosp N Staffordshire, Univ Leeds, Univ London } \\
\text { Imperial Coll, Univ Mersin, Univ Paris, Upmc Hop La Pitie Salpetriere, Wake } \\
\text { Forest Univ, Wythenshawe Hosp, Yokohama City Univ, Yonsei Univ }\end{array}$ \\
\hline
\end{tabular}

the total number of citations $(r=0.506 ; p<0.01)$ (Table 4).

When the countries of the first authors were evaluated, $42 \%$ were determined to be Turkey, and $13 \%$ were Japan, $69 \%$ were European, and $31 \%$ were non-European. When the countries of the journals were evaluated, $56 \%$ were identified to be America, and $27 \%$ were identified to be England. When the journals were evaluated on a continental basis, they were determined as 35\% European and $65 \%$ non-European journals (Table 2 ).

While there was no significant relationship between the author's continent, the continent of the journal and the type of study, and the total and the annual number of citations ( $p>0.05)$, a significant relationship was found between the year of publication of the article, the $q$ index and class of the journal and the number of annual citations $(p<0.001)$. In addition, a significant relationship was found between the topic of the study and the presence of an author group in the study and both the average number of citations and the annual number of citations. The specialties of the authors responsible for the articles were 35\% Rheumatology, 15\% Ophthalmology, 12\% Internal Medicine, 7\% Dermatology, 7\% Immunology, 6\% Neurology, and $18 \%$ other specialties. Of the 100 most cited studies on $\mathrm{BD}, 48 \%$ were prospective studies, $24 \%$ were reviews, $20 \%$ were retrospectives, $2 \%$ were guidelines, and $6 \%$ were other studies. It was found that both the total and average annual citation numbers of guideline-enabled study types were higher. When viewed by year, it is seen that retrospective studies and compilations decrease over time (Fig. 4).

According to the Web of Science journal classes, $39 \%$ of the studies were in the category of rheumatology, $15 \%$ in "Medicine, General \& Internal, and $10 \%$ in immunology (Table 3 ). The total and average annual citations of publications published in journals in the Genetics \& Heredity category were found to be higher.

\section{DISCUSSION}

$\mathrm{BD}$ is a chronic systemic inflammatory vasculitis that shows recurrent oral and genital ulcerations, cutaneous lesions, ophthalmic, neurological, and gastrointestinal involvement (10). Although environmental and genetic factors contribute to this disease, which is spreading globally worldwide but is more commonly detected in the silk road population, the mechanism of the disease remains unclear (10). The estimated prevelance in Turkey is between 20 and 420 per 100,000 and $13.5-30$ per 100,000 in other Asian countries (12). Estimated prevelance was found to be lower in western countries, with 0.12 to 0.33 in 100,000 in the United States and 0.64 in 100,000 in the United Kingdom(12). These days when rheumatological diseases are important in the clinic, it is crucial to follow the developments related to $\mathrm{BD}$, one of the crucial rheumatological diseases. Therefore, it is necessary for every clinician to know $\mathrm{BD}$ well and to follow the future of developments and 
Table 3. The characteristics of the 100 articles about Behcet's Disease in the literature.

\begin{tabular}{|c|c|c|c|c|c|c|}
\hline Parameters & Subgroups & $\mathrm{n}$ & $\begin{array}{c}\text { Total number of } \\
\text { citations } \\
\text { mean } \pm S D\end{array}$ & $\begin{array}{c}\text { Citiations per year(mean } \\
\text { Citiations) } \\
\text { mean } \pm \text { SD }\end{array}$ & $\begin{array}{c}\mathbf{p} \\
\text { (Total } \\
\text { number of } \\
\text { citations) }\end{array}$ & $\begin{array}{c}p \\
\text { (Citiations per } \\
\text { year) }\end{array}$ \\
\hline \multirow[t]{7}{*}{ Year } & $<1990$ & 18 & $372,44 \pm 664,38$ & $10,92 \pm 20,92$ & \multirow[t]{7}{*}{0,979} & \multirow[t]{7}{*}{$<0,001$} \\
\hline & 1991-1994 & 9 & $210,44 \pm 103,91$ & $7,08 \pm 3,50$ & & \\
\hline & 1995-1999 & 21 & $264,61 \pm 249,32$ & $11,14 \pm 10,92$ & & \\
\hline & $2000-2004$ & 26 & $209,76 \pm 83,60$ & $10,68 \pm 4,47$ & & \\
\hline & $2005-2009$ & 13 & $222,15 \pm 87,14$ & $15,39 \pm 6,29$ & & \\
\hline & $2010-2014$ & 11 & $251 \pm 128,33$ & $24,01 \pm 15,92$ & & \\
\hline & $>2015$ & 2 & $188,50 \pm 14,84$ & $47,12 \pm 3,71$ & & \\
\hline \multirow[t]{2}{*}{ Author's Continent } & Europe & 69 & $256,08 \pm 348,40$ & $12,63 \pm 12,27$ & \multirow[t]{2}{*}{0,988} & \multirow[t]{2}{*}{0,456} \\
\hline & Non-Europe & 31 & $256,93 \pm 212,47$ & $14,80 \pm 15,75$ & & \\
\hline \multirow[t]{9}{*}{ Author's Country } & Turkey & 42 & $227,38 \pm 105,66$ & $11,42 \pm 8,51$ & \multirow[t]{9}{*}{0,183} & \multirow[t]{9}{*}{0,566} \\
\hline & Japan & 13 & $329,76 \pm 294,88$ & $15,61 \pm 15,40$ & & \\
\hline & Other & 10 & $206,10 \pm 110,11$ & $14,14 \pm 17,42$ & & \\
\hline & England & 9 & $511,88 \pm 937,81$ & $20,18 \pm 28,19$ & & \\
\hline & USA & 8 & $199,87 \pm 108,58$ & $9,96 \pm 10,58$ & & \\
\hline & Greece & 6 & $243 \pm 90,49$ & $13,64 \pm 4,08$ & & \\
\hline & France & 6 & $169,50 \pm 34,55$ & $12 \pm 5,24$ & & \\
\hline & China & 3 & $178,66 \pm 43$ & $21,63 \pm 20,60$ & & \\
\hline & Germany & 3 & $173,33 \pm 9,29$ & $8,77 \pm 1,24$ & & \\
\hline \multirow[t]{7}{*}{ Author's Branch } & Rheumatology & 35 & $231,02 \pm 105,50$ & $13,40 \pm 12,29$ & \multirow[t]{7}{*}{0,062} & \multirow[t]{7}{*}{0,284} \\
\hline & Other & 18 & $331,61 \pm 671,71$ & $14,98 \pm 22,65$ & & \\
\hline & Ophtalmology & 15 & $256,06 \pm 81,42$ & $13,13 \pm 6,94$ & & \\
\hline & $\begin{array}{l}\text { Internal } \\
\text { Diseases }\end{array}$ & 12 & $206,16 \pm 96,50$ & $10,05 \pm 5,55$ & & \\
\hline & Immunology & 7 & $354,42 \pm 409,81$ & $19,60 \pm 18,59$ & & \\
\hline & Dermatology & 7 & $175,28 \pm 34,90$ & $9,01 \pm 2,02$ & & \\
\hline & Neurology & 6 & $259,50 \pm 127,68$ & $12,32 \pm 6,76$ & & \\
\hline \multirow[t]{2}{*}{ Group of authors } & No & 98 & $251,23 \pm 312,62$ & $12,71 \pm 12,54$ & \multirow[t]{2}{*}{0,004} & \multirow[t]{2}{*}{0,015} \\
\hline & Yes & 2 & $507 \pm 11,31$ & $42,38 \pm 28,27$ & & \\
\hline \multirow[t]{4}{*}{ Journal Q Index } & Q1 & 69 & $277,01 \pm 369,79$ & $15,16 \pm 15,48$ & \multirow[t]{4}{*}{0,589} & \multirow[t]{4}{*}{0,038} \\
\hline & Q2 & 21 & $201,09 \pm 78,90$ & $8,0929 \pm 4,15457$ & & \\
\hline & Q3 & 8 & $103,26 \pm 103,26$ & $12,28 \pm 5,84$ & & \\
\hline & Q4 & 2 & $211 \pm 94,75$ & $8,16 \pm 5,55$ & & \\
\hline \multirow[t]{4}{*}{ Journal's Country } & USA & 56 & $239,73 \pm 168,54$ & $13,77 \pm 12,09$ & \multirow[t]{4}{*}{0,791} & \multirow[t]{4}{*}{0,366} \\
\hline & England & 27 & $326,40 \pm 545,64$ & $15,21 \pm 18,57$ & & \\
\hline & Canada & 9 & $218,22 \pm 105,21$ & $8,58 \pm 4,47$ & & \\
\hline & Other & 8 & $179,12 \pm 33,61$ & $8,91 \pm 4,65$ & & \\
\hline \multirow[t]{2}{*}{ Journal's Continent } & Non Europe & 65 & $236,75 \pm 160,78$ & $13,05 \pm 11,46$ & \multirow[t]{2}{*}{0,508} & \multirow[t]{2}{*}{0,820} \\
\hline & Europe & 35 & $292,74 \pm 481,50$ & $13,77 \pm 16,60$ & & \\
\hline
\end{tabular}


Table 3. Continue

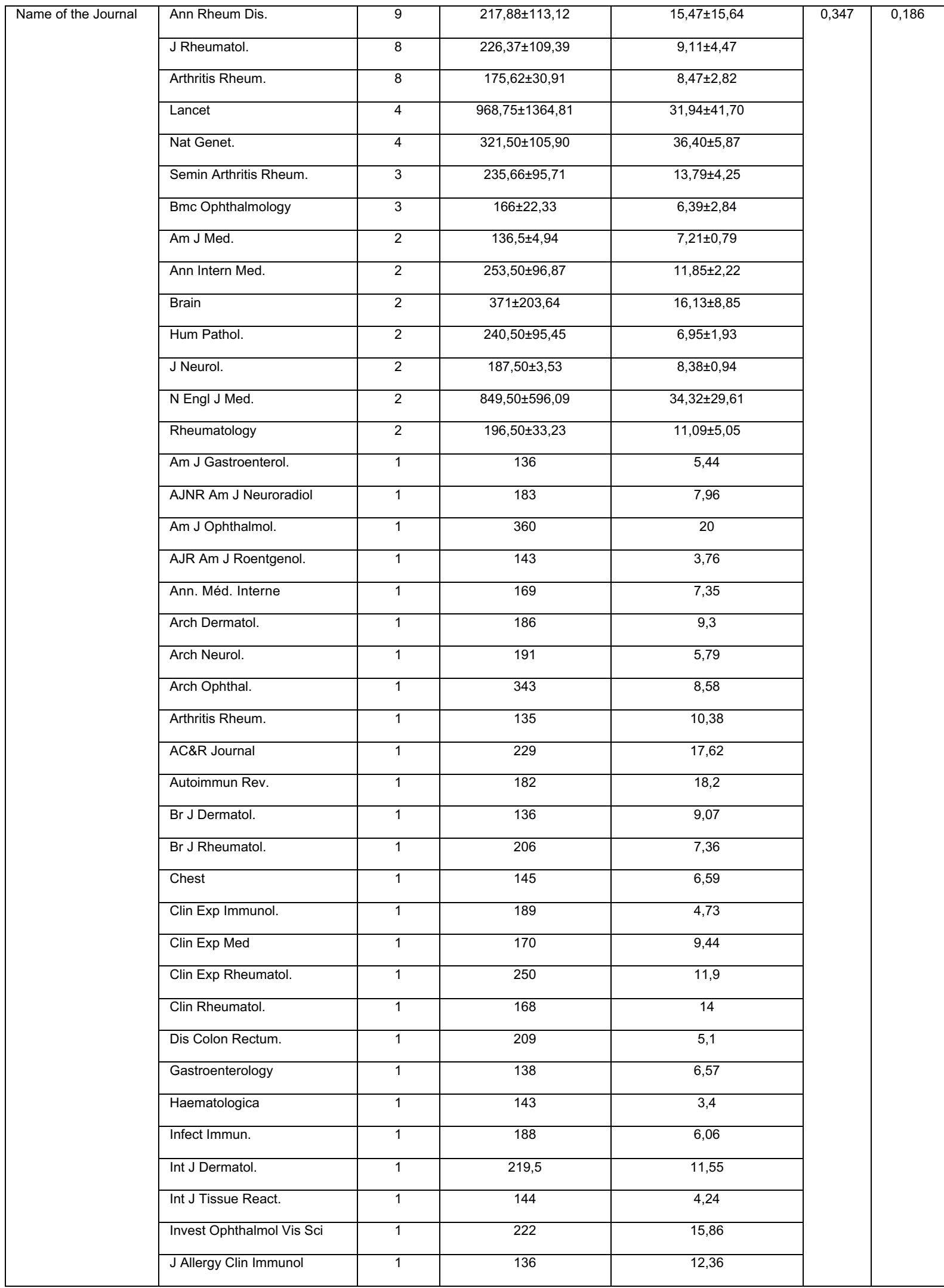


Table 3. Continue

\begin{tabular}{|c|c|c|c|c|c|c|}
\hline & J Autoimmun. & 1 & 198 & 15,23 & & \\
\hline & J Immunol. & 1 & 133 & 4,59 & & \\
\hline & J Pediatr. & 1 & $164 \pm 153$ & $6,83 \pm 4,37$ & & \\
\hline & J Rheumatolog & 1 & 153 & 4,37 & & \\
\hline & J Am Acad Dermatol. & 1 & 147 & 6,39 & & \\
\hline & J Am Coll Cardiol. & 1 & 164 & 7,81 & & \\
\hline & $\begin{array}{l}\text { J. Eur. Acad. Dermatol. } \\
\text { Venereol. }\end{array}$ & 1 & 499 & 62,38 & & \\
\hline & Lancet Neurol. & 1 & 249 & 19,15 & & \\
\hline & Mediators Inflamm. & 1 & 169 & 8,45 & & \\
\hline & Medicine & 1 & 475 & 25 & & \\
\hline & Nat Clin Pract Rheumatol. & 1 & 191 & 12,73 & & \\
\hline & Neurology & 1 & 170 & 5,67 & & \\
\hline & Ophthalmology & 1 & 177 & 19,67 & & \\
\hline & Proc Natl Acad Sci U S A. & 1 & 331 & 13,24 & & \\
\hline & Rheum Dis Clin North Am. & 1 & 138 & 4,31 & & \\
\hline & Scand J Rheumatol Suppl & 1 & 267 & 13,35 & & \\
\hline & Surgery & 1 & 154 & 6,16 & & \\
\hline & Surv Ophthalmol & & 278 & 16,35 & & \\
\hline & Thorax & 1 & 147 & 7 & & \\
\hline & Tissue Antigens & 1 & 278 & 12,09 & & \\
\hline Journal's Category & Rheumatology & 39 & $205,48 \pm 80,68$ & $11,27 \pm 8,36$ & 0,099 & 0,030 \\
\hline & Medicine, General \& Internal & 15 & $510,86 \pm 747,40$ & $19,82 \pm 23,95$ & & \\
\hline & Immunology & 10 & $190,90 \pm 86,42$ & $11,28 \pm 9,94$ & & \\
\hline & Ophthalmology & 8 & $234,75 \pm 82,76$ & $12,45 \pm 6,29$ & & \\
\hline & Clinical Neurology & 7 & $246,71 \pm 121,37$ & $11,37 \pm 6,66$ & & \\
\hline & Dermatology & 6 & $234,50 \pm 134,45$ & $21,64 \pm 18,37$ & & \\
\hline & Other & 6 & $156 \pm 15,28$ & $6,38 \pm 1,41$ & & \\
\hline & Genetics \& Heredity & 3 & $286,33 \pm 96,96$ & $36,67 \pm 7,16$ & & \\
\hline & Pathology & 3 & $253 \pm 70,88$ & $8,66 \pm 3,26$ & & \\
\hline & $\begin{array}{l}\text { Gastroenterology \& } \\
\text { Hepatology }\end{array}$ & 3 & $161 \pm 41,58$ & $5,70 \pm 0,76$ & & \\
\hline Article Type & Prospective & 48 & $276,14 \pm 413,50$ & $13,96 \pm 16,42$ & 0,249 & 0,080 \\
\hline & Review & 24 & $251,75 \pm 224$ & $13,13 \pm 9,96$ & & \\
\hline & Retrospective & 20 & $234,35 \pm 121,24$ & $10,56 \pm 5,76$ & & \\
\hline & Other & 6 & $163 \pm 37,01$ & $8,35 \pm 5,08$ & & \\
\hline & Guideline & 2 & $336,50 \pm 194,45$ & $41,80 \pm 11,23$ & & \\
\hline Article Topic & Treatment & 26 & $219 \pm 93,56$ & $12,69 \pm 9,61$ & 0,022 & $<0,001$ \\
\hline & Pathogenesis & 17 & $190,35 \pm 49,75$ & $8,93 \pm 4,08$ & & \\
\hline & Vasculobehcet & 14 & $174,85 \pm 83,19$ & $6,35 \pm 2,82$ & & \\
\hline & Diagnostic Criteria & 2 & $1754,50 \pm 1775,54$ & $78,22 \pm 22,40$ & & \\
\hline & Mortality & 2 & $305,50 \pm 239,70$ & $18,16 \pm 9,66$ & & \\
\hline & Ocular Behcet & 2 & $268,50 \pm 129,40$ & $19,83 \pm 0,23$ & & \\
\hline
\end{tabular}


studies. Bibliometric studies can be a guide in $\mathrm{BD}$, as in other areas where they are carried out. Using the Web of Science search engine, valuable information such as database, academic personal citation statistics, average citation indexes can be accessed $(1,13)$.

Bibliometric studies have been carried out in various disciplines around the world and our country. In the 100 most cited studies in Rheumatoid Arthritis conducted by Yin et al. (13), it is seen that the studies were mostly conducted between 2000-2004, and the studies were mostly conducted between 2001 and 2007 when they examined the 100 most cited articles in Psoriatic arthritis by Berlinberg et al. (14). Like the literature, the most studied years in our study were between 2000 and 2004, with 26 studies. While a significant relationship was found between the increasing years and the average number of citations per year, no significant correlation was found with the total number of citations. In this respect, our study is similar to the studies of Büyükçoban et al. (15) The relevant situation indicates that the information is upto-date, new information rapidly replaces old information, and is frequently used.

In the bibliometric study of Akyol et al. (16), including publications on rehabilitation in Ankylosing Spondylitis, the authors were mostly from Germany, followed by Turkey and the USA, Bagcier et al. (17) In his study of the most cited articles in ankylosing spondylitis, it was determined that the authors were mostly nationals of Germany, the Netherlands and then the United Kingdom, respectively. Turkey, Japan, and then the United Kingdom were the countries that contributed the most to the BD-related studies in our study. This can be explained by the interest of Turkish authors in the disease since Behcet's disease was more common in Turkey, and the person who identified the disease was a Turkish dermatologist.

Our study was mostly written by rheumatologists and then by ophthalmologists and internal medicine specialists, as in the study of Berlinberg et al. (14), in which 100 most cited articles on psoriatic arthritis were evaluated. Uveitis, a common complication of $\mathrm{BD}$, is under the attention of ophthalmologists. Again, a significant relationship was found between the presence of Group Authors in the studies and both the total number of citations $(p<0.004)$ and the average annual number of citations (p0.015). This indicates that the studies, which are multi-centered and include many experts in their fields, are of higher quality and value.

In the study of Kwan et al. (18), which included the 100 most cited articles in the field of Rheumatology, the journal with the most articles was found to be "Arthritis and Rheumatism" and then the "New England Journal of Medicine." In the study of Bagcier et al. (17), the largest number of studies were published in the journal "Arthritis and Rheumatism" and then in the "Annals of the Rheumatic Diseases" journal. In our study, the most cited studies on BD were "Annals of the Rheumatic Diseases" (9\%), "Journal of Rheumatology" (8\%), and "Arthritis and Rheumatism"(8\%), respectively. Our study shows similarities compared with the journals in which the most cited other rheumatic diseases were published. In the studies of Yin et al. (13) on Rheumatoid Arthritis and Buyukcoban et al. (15) on the 100 most cited articles on geriatric anesthesia, most studies were published in journals from the USA, followed by journals from the UK. Our study is similar to the literature in this aspect.

In our study, we found that more publications were made in developed countries, as in the study of Şenel et al. (19). On the other hand, it is known that the

Table 4. Correlation relationships and correlation coefficients between the number of citations, publication year and journal impact of the 100 most cited studies on Behçet's disease (r)

\begin{tabular}{|l|l|l|l|l|}
\hline & $\begin{array}{l}\text { Number of } \\
\text { Citiation }\end{array}$ & $\begin{array}{l}\text { Average Number } \\
\text { of Citations per } \\
\text { Year }\end{array}$ & $\begin{array}{l}\text { Journal Impact } \\
\text { factor }\end{array}$ & Year of Publication \\
\hline Number of Citiation & 1 & $0,781^{* *}$ & $0,506^{* *}$ & $-0,076$ \\
\hline $\begin{array}{l}\text { Average Number of } \\
\text { Citations per Year }\end{array}$ & $0,781^{* *}$ & 1 & $0,462^{* *}$ & $0,382^{* *}$ \\
\hline Journal Impact factor & $0,506^{* *}$ & $0,462^{* *}$ & 1 & 0,012 \\
\hline Year of Publication & $-0,076$ & $0,382^{* *}$ & 0,012 & 1 \\
\hline
\end{tabular}

${ }^{*} p<0.05$, Pearson correlation analysis; ${ }^{* *} p<0,001$ Pearson correlation analysis 
Table 5. Overall and mean annular citation numbers and PubMed reference number (PMID) of the 100 articles about Behcet's Disease in the literature.

\begin{tabular}{|c|c|c|c|c|}
\hline Number & $\begin{array}{l}\text { The names of the } \\
\text { authors and years }\end{array}$ & PMID & $\begin{array}{l}\text { Number of } \\
\text { Citation }\end{array}$ & $\begin{array}{l}\text { Mean } \\
\text { Annular } \\
\text { Citation } \\
\text { number }\end{array}$ \\
\hline 1 & Silman AJ, 1990 & 1970380 & 3010 & 94,06 \\
\hline 2 & $\begin{array}{l}\text { Sakane T et al, } \\
1999\end{array}$ & 10528040 & 1271 & 55,26 \\
\hline 3 & $\begin{array}{l}\text { Akman-Demir G et } \\
\text { al, } 1999\end{array}$ & 10545401 & 515 & 22,39 \\
\hline 4 & $\begin{array}{l}\text { Davatchi F et al, } \\
2014\end{array}$ & 23441863 & 499 & 62,38 \\
\hline 5 & $\begin{array}{l}\text { Kural-Seyahi E et al, } \\
2003\end{array}$ & 12544711 & 475 & 25 \\
\hline 6 & Hatemi G et al, 2008 & 18245110 & 474 & 33,86 \\
\hline 7 & Koc Y et al, 1992 & 1578454 & 455 & 15,17 \\
\hline 8 & Yazici H et al, 1990 & 2404204 & 428 & 13,38 \\
\hline 9 & $\begin{array}{l}\text { Remmers EF et al, } \\
2010\end{array}$ & 20622878 & 427 & 35,58 \\
\hline 10 & $\begin{array}{l}\text { Sfikakis PP et al, } \\
2001\end{array}$ & 11498218 & 366 & 17,43 \\
\hline 11 & $\begin{array}{l}\text { Mizuki, N. et al, } \\
2010\end{array}$ & 20622879 & 365 & 30,42 \\
\hline 12 & $\begin{array}{l}\text { Tugal-Tutkun I et al, } \\
2004\end{array}$ & 15364218 & 360 & 20 \\
\hline 13 & $\begin{array}{l}\text { Masuda K et al, } \\
1989\end{array}$ & 2566048 & 358 & 10,85 \\
\hline 14 & $\begin{array}{l}\text { Kaklamani VG et al, } \\
1998\end{array}$ & 9514126 & 345 & 14,38 \\
\hline 15 & Ohno S et al, 1982 & 6956266 & 343 & 8,58 \\
\hline 16 & Mizuki $\mathrm{N}$ et al, 1997 & 9037047 & 331 & 13,24 \\
\hline 17 & $\begin{array}{l}\text { Hamuryudan V et al, } \\
1998\end{array}$ & 9499327 & 322 & 13,42 \\
\hline 18 & Kirino, Y et al, 2013 & 23291587 & 316 & 35,11 \\
\hline 19 & $\begin{array}{l}\text { Lakhanpal S et al, } \\
1985\end{array}$ & 4018777 & 308 & 8,32 \\
\hline 20 & Yazici H et al, 1984 & 6524980 & 306 & 8,05 \\
\hline 21 & Mege JL et al, 1993 & 8164212 & 292 & 10,07 \\
\hline 22 & $\begin{array}{l}\text { Evereklioglu C, } \\
2005\end{array}$ & 15967189 & 278 & 16,35 \\
\hline 23 & $\begin{array}{l}\text { Verity DH et al, } \\
1999\end{array}$ & 10519357 & 278 & 12,09 \\
\hline 24 & Ohno S et al, 2004 & 15229958 & 268 & 14,89 \\
\hline 25 & $\begin{array}{l}\text { Hamzaoui K et al, } \\
2002\end{array}$ & 12369651 & 267 & 13,35 \\
\hline 26 & Direskeneli H, 2001 & 11602462 & 258 & 12,29 \\
\hline 27 & Gül A, 2001 & 11760403 & 250 & 11,9 \\
\hline 28 & $\begin{array}{l}\text { Al-Araji A et al, } \\
2009\end{array}$ & 19161910 & 249 & 19,15 \\
\hline 29 & $\begin{array}{l}\text { Azizlerli G et al, } \\
2003\end{array}$ & 14521694 & 231 & 12,16 \\
\hline 30 & $\begin{array}{l}\text { de Menthon M et al, } \\
2009\end{array}$ & 19790126 & 229 & 17,62 \\
\hline 31 & Kidd D et al, 1999 & 10545402 & 227 & 9,87 \\
\hline 32 & Chi, W et al ,2008 & 18579762 & 222 & 15,86 \\
\hline
\end{tabular}

\section{Table 5. Continue}

\begin{tabular}{|c|c|c|c|c|}
\hline 33 & $\begin{array}{l}\text { Sfikakis PP et al, } \\
2007\end{array}$ & 17403712 & 220 & 14,67 \\
\hline 34 & $\begin{array}{l}\text { Yurdakul S et al, } \\
2001\end{array}$ & 11710724 & 219 & 10,43 \\
\hline 35 & $\begin{array}{l}\text { Tugal-Tutkun I et al, } \\
2005\end{array}$ & 16052571 & 215 & 12,65 \\
\hline 36 & $\begin{array}{l}\text { Kasahara Y et al, } \\
1981\end{array}$ & 7215071 & 209 & 5,1 \\
\hline 37 & Tursen U et al, 2003 & 12755969 & 208 & 10,95 \\
\hline 38 & $\begin{array}{l}\text { Hamuryudan V et al, } \\
1994\end{array}$ & 8162457 & 206 & 7,36 \\
\hline 39 & $\begin{array}{l}\text { Melikoglu M et al, } \\
2005\end{array}$ & 15630733 & 201 & 11,82 \\
\hline 40 & Hatemi G et al, 2018 & 29625968 & 199 & 49,75 \\
\hline 41 & $\begin{array}{l}\text { Mendes D et al, } \\
2009\end{array}$ & 19324519 & 198 & 15,23 \\
\hline 42 & Arida A et al, 2011 & 21168186 & 195 & 17,73 \\
\hline 44 & $\begin{array}{l}\text { Serdaroglu } \mathrm{P} \text { et al, } \\
1989\end{array}$ & 2919979 & 191 & 5,79 \\
\hline 43 & Yazici H et al, 2007 & 17334337 & 191 & 12,73 \\
\hline 45 & Siva A et al, 2001 & 11284141 & 190 & 9,05 \\
\hline 46 & Niwa Y et al, 1982 & 7127901 & 189 & 4,73 \\
\hline 47 & Lehner T et al, 1991 & 2004821 & 188 & 6,06 \\
\hline 48 & $\begin{array}{l}\text { Frassanito MA et al, } \\
1999\end{array}$ & 10513814 & 187 & 8,13 \\
\hline 49 & Alpsoy E et al, 2002 & 11939808 & 186 & 9,3 \\
\hline 50 & $\begin{array}{l}\text { Hamuryudan V et al, } \\
1997\end{array}$ & 9125262 & 185 & 7,4 \\
\hline 51 & $\begin{array}{l}\text { Serdaroglu P et al, } \\
1998\end{array}$ & 9591220 & 185 & 7,71 \\
\hline 52 & $\begin{array}{l}\text { Sfikakis PP et al, } \\
2004\end{array}$ & 14996689 & 185 & 10,28 \\
\hline 53 & Kotter I et al, 2003 & 12642304 & 184 & 9,68 \\
\hline 54 & Kocer $\mathrm{N}$ et al, 1999 & 10445437 & 183 & 7,96 \\
\hline 55 & $\begin{array}{l}\text { de Chambrun MP et } \\
\text { al, } 2012\end{array}$ & 22197900 & 182 & 18,2 \\
\hline 56 & Zhou Q et al, 2016 & 26642243 & 178 & 44,5 \\
\hline 57 & Dick AD et al, 2013 & 23290985 & 177 & 19,67 \\
\hline 58 & $\begin{array}{l}\text { Benezra D et al, } \\
1986\end{array}$ & 3741823 & 173 & 4,81 \\
\hline 59 & $\begin{array}{l}\text { Bhakta BB et al, } \\
1999\end{array}$ & 10501420 & 173 & 7,52 \\
\hline 60 & $\begin{array}{l}\text { Matsumoto T et al, } \\
1991\end{array}$ & 1985077 & 173 & 5,58 \\
\hline 61 & $\begin{array}{l}\text { Kurokawa MS et al, } \\
2004\end{array}$ & 16088499 & 170 & 9,44 \\
\hline 62 & $\begin{array}{l}\text { Wechsler B et al, } \\
1992\end{array}$ & 1549224 & 170 & 5,67 \\
\hline 63 & $\begin{array}{l}\text { Evereklioglu, C et al, } \\
2002\end{array}$ & 12061429 & 169 & 8,45 \\
\hline 64 & $\begin{array}{l}\text { Zouboulis CC et al, } \\
1999\end{array}$ & 10615535 & 169 & 7,35 \\
\hline 65 & $\begin{array}{l}\text { Davatchi F et al, } \\
2010\end{array}$ & 20354748 & 168 & 14 \\
\hline 66 & Kotter I et al, 2004 & 15079763 & 167 & 9,28 \\
\hline 67 & $\begin{array}{l}\text { Yurdakul S et al, } \\
1998\end{array}$ & 3172095 & 165 & 4,85 \\
\hline 68 & $\begin{array}{l}\text { Chambers JC et al, } \\
2001\end{array}$ & 11216972 & 164 & 7,81 \\
\hline
\end{tabular}


Table 5. Continue

\begin{tabular}{|c|c|c|c|c|}
\hline 69 & $\begin{array}{l}\text { Koné-Paut I et } \\
\text { al, } 2001\end{array}$ & 9580778 & 164 & 6,83 \\
\hline 70 & $\begin{array}{l}\text { Nussenblat RB } \\
\text { et al, } 1985\end{array}$ & 4004976 & 163 & 4,41 \\
\hline 71 & Gul A et al, 2012 & 22084392 & 160 & 7,41 \\
\hline 72 & $\begin{array}{l}\text { Turan B et al, } \\
1997\end{array}$ & 9002023 & 159 & 6,36 \\
\hline 73 & $\begin{array}{l}\text { Tuzun H et al, } \\
1997\end{array}$ & 9037226 & 154 & 6,16 \\
\hline 74 & Hamza M, 1987 & 3625635 & 153 & 4,37 \\
\hline 75 & $\begin{array}{l}\text { Lee } \mathrm{KH} \text { et al, } \\
2003\end{array}$ & 12847697 & 150 & 7,89 \\
\hline 76 & $\begin{array}{l}\text { Takeno M et al, } \\
1995\end{array}$ & 7880197 & 150 & 5,56 \\
\hline 77 & $\begin{array}{l}\text { Erkan F et al, } \\
2001\end{array}$ & 11413359 & 147 & 7 \\
\hline 78 & $\begin{array}{l}\text { Ghate JV et al, } \\
1999\end{array}$ & 9922007 & 147 & 6,39 \\
\hline 79 & $\begin{array}{l}\text { Sfikakis PP et al, } \\
2002\end{array}$ & 12379622 & 147 & 7,35 \\
\hline 80 & $\begin{array}{l}\text { Mogulkoc } \mathrm{N} \text { et } \\
\mathrm{al}, 2000\end{array}$ & 10936144 & 145 & 6,59 \\
\hline 81 & $\begin{array}{l}\text { Mizushima Y, } \\
1988\end{array}$ & 3053482 & 144 & 4,24 \\
\hline 83 & $\begin{array}{l}\text { Aktulga E et al, } \\
1980\end{array}$ & 6778795 & 143 & 3,4 \\
\hline 82 & $\begin{array}{l}\text { Park JH et al, } \\
1984\end{array}$ & 6332492 & 143 & 3,76 \\
\hline 84 & $\begin{array}{l}\text { Hasan A et al, } \\
1996\end{array}$ & 8622334 & 141 & 5,42 \\
\hline 85 & $\begin{array}{l}\text { Ozyazgan Y et } \\
\text { al, } 1992\end{array}$ & 1390495 & 141 & 4,7 \\
\hline 86 & $\begin{array}{l}\text { Hamuryudan V } \\
\text { et al, } 2004\end{array}$ & 15589493 & 140 & 7,78 \\
\hline 87 & $\begin{array}{l}\text { Hatemi G et al, } \\
2009\end{array}$ & 18420940 & 140 & 10,77 \\
\hline 88 & $\begin{array}{l}\text { Yurdakul S et al, } \\
1983\end{array}$ & 6625699 & 140 & 3,59 \\
\hline 89 & $\begin{array}{l}\text { Hassard PV et } \\
\text { al, } 2001\end{array}$ & 11231954 & 138 & 6,57 \\
\hline 90 & $\begin{array}{l}\text { Oduffy JD et al, } \\
1990\end{array}$ & 2189158 & 138 & 4,31 \\
\hline 91 & Gul A et al, 2000 & 10913059 & 137 & 6,23 \\
\hline 92 & $\begin{array}{l}\text { Alpsoy E et al, } \\
2007\end{array}$ & 17711526 & 136 & 9,07 \\
\hline 93 & $\begin{array}{l}\text { Bayraktar Y et } \\
\text { al, } 1997\end{array}$ & 9149201 & 136 & 5,44 \\
\hline 94 & $\begin{array}{l}\text { Geri G et al, } \\
2011\end{array}$ & 21724243 & 136 & 12,36 \\
\hline 95 & Lie JT, 1992 & 1578445 & 136 & 4,53 \\
\hline 96 & $\begin{array}{l}\text { Saadoun D et al, } \\
2010\end{array}$ & 20496419 & 136 & 11,33 \\
\hline 97 & $\begin{array}{l}\text { Calamia KT et } \\
\text { al, } 2009\end{array}$ & 19405011 & 135 & 10,38 \\
\hline 98 & $\begin{array}{l}\text { Sayinalp N et al, } \\
1996\end{array}$ & 8882039 & 135 & 5,19 \\
\hline 99 & $\begin{array}{l}\text { Espinosa G et al, } \\
2002\end{array}$ & 11812405 & 133 & 6,65 \\
\hline 100 & $\begin{array}{l}\text { Pervin K et al, } \\
1993\end{array}$ & 7688396 & 133 & 4,59 \\
\hline
\end{tabular}

PMID: PubMed reference number

prevalence of the disease is higher in undeveloped or developing countries.
In the study conducted by Berlinberg et al. (14), in which the 100 most cited articles in psoriatic arthritis were evaluated, the journals in which the studies were included were mostly in the field of Dermatology after Rheumatology, while in our study, Medicine, General \& Internal was the field after Rheumatology the most. Although our study is similar to the literature in this aspect, a significant relationship was found between the journal class and the annual average number of citations $(p<0.030)$. The relevant situation indicates that the authors submitted their studies to the journals they selected by looking at the journal categories, and therefore, more citations occurred in the specific journal categories. Berlinberg et al. (14) stated that the researchers sent their studies to journals with high impact factors and that the number of citations in these journals was high. Similarly, there is a significant relationship between the high journal impact factor and the total and annual citation count in our study. It was observed that the total number of citations was higher in journals with high impact factors.

In the study conducted by Yin et al. (13), when the study types were examined, it was reported that the reviews came after the randomized controlled, prospective clinical study types. Similarly, in the study of Bagcier et al. (17), randomized controlled, prospective clinical study types are in the first place. Similar to the literature, randomized controlled, prospective clinical study is in the first place in our study, followed by reviews. In our study, when we look at the years, compilation and observational retrospective studies have left their place to guideline and prospective studies.

In the study conducted by Bagcier et al. (17), in which the most cited articles on Ankylosing Spondylitis were evaluated, the first line of treatment was treatment, followed by disease activity and pathogenesis. In the study of Yin et al. (13), treatment is the first line, followed by pathogenesis and risk factors. In our study, treatment $(n=26)$ was the first line, followed by pathogenesis $(n=17)$. Our study is similar to the literature in this respect. In addition, in our study, there is a significant relationship between the study subject and the total number of citations $(p=0.022)$ and the annual average number of citations $(p<0.001)$. We can explain this situation by making more references to current popular topics related to the disease by the researchers. Considering the years, research on pathogenesis has decreased and left its place in treatment and genetics. Thanks to 
bibliometric analyses, future study topics will change according to need (20).

The most important limitation of our study is that the search keys used when searching the Web of Science database and enabling the algorithm to find and list the relevant publications are given by the Web of Science itself, and some studies on the subject cannot be included in the list resulting from the search. However, although this rate is very low, it is not a limitation specific to this study, and all studies on this subject have the same limitation.

As a result, our study examining the citation numbers of international articles on BD is a valuable study in this respect. In this study, the Institute for Scientific Information and Web of Science search engine (11) made an evaluation of the most cited internationally sourced articles about BD, examining these articles according to authors, countries, and institutions, and evaluating which journals they were published in. As a result of our study, it was found that the annual number of citations increased for newer studies, both total and average annual citations were higher for studies with a group of authors, annual citation numbers were higher in Q1 journals, journals in the Genetics \& Heredity category received more average annual citations, articles dealing with diagnostic criteria had more citations, and finally, guidelinespecific study types were found to have more citations. The bibliographic articles created by using scientific search engines are guiding on which subject to focus on researches. It is also recommended that such studies be updated and rewritten at certain time intervals to carry out healthy data analysis.

Acknowledgment: The Authors thank University Hospital for their valuable technical assistance.

Author contributions: Concept - E.O, V.H.; Design - E.O, V.H.; Supervision - V.H.; Data Collection and/or Processing - E.O.; Analysis and/or Interpretation -V.H.; Literature Search - E.O.; Writing Manuscript - E.O.,V.H.; Critical Review - V.H.

Conflict of Interest: The authors declare no conficts of interest. Ethical Approval: No human participants/animals were evaluted. The study was approved by Non-Interventional Clinical Research Ethics Committee (protocol number6272-GOA 2021/1631,27.05.2021).

Funding: The authors received no financial support for the research, authorship, and/or publication of this article.

Peer-review: Externally peer-reviewed.

\section{REFERENCES}

1. Terajima K, Aneman A. Citation classics in anaesthesia and pain journals: a literature review in the era of the internet. Acta Anaesthesiol Scand. 2003;47:655-63.
2. Ang HM, Kwan $\mathrm{YH}$. Bibliometric analysis of journals in the field of geriatrics and gerontology. Geriatr Gerontol Int. 2017; 17:357-360.

3. Garfield E. 100 citation classics from the journal of the American Medical Association, JAMA 1987;257:52-9.

4. Ohba N, Nakao K, Isashiki Y. The 101 most frequently cited articles in ophthalmology journals from1850 to 1950. Arch Ophthalmol 2010;128:1610-7.

5. Paladugu R, Schein M, Gardezi S, Wise L. One hundred citation classics in general surgical journals. World J Surg. 2002;26(9):1099-1105.

6. Bağcıer F, Inal Yorulmaz E, Çağlar Yağcı H. Top 100 cited articles on fibromyalgia syndrome: A bibliometric and altmetric analyses study. Agri. 2021;33:53-63

7. Kreutzer JS, Agyemang AA, Weedon D, et al. The top 100 cited neurorehabilitation papers. NeuroRehabilitation. 2017;40(2):163-174.

8. Hatemi G, Seyahi E, Fresko I, Talarico R, Hamuryudan V. One year in review 2020: Behçet's syndrome. Clin Exp Rheumatol. 2020;38 Suppl 127(5):3-10.

9. Davatchi F, Chams-Davatchi $\mathrm{C}$, Shams $\mathrm{H}$, et al. Behcet's disease: epidemiology, clinical manifestations, and diagnosis. Expert Rev Clin Immunol. 2017 Jan;13(1):57-65.

10. Chen J, Yao X. A Contemporary Review of Behcet's Syndrome Clin Rev Allergy Immunol. 2021;10.1007/s12016-021-08864-3.

11. Thomson Scientific ISI Web of Knowledge: http://scientific.thomson.com/webofknowledge.

12. Jabs DA, Dick AD, Dunn JP, et al. Classification criteria for Behçet Disease Uveitis Am J Ophthalmol. 2021;S0002-9394(21)00183-5

13. Yin $X$, Cheng $F$, Wang $X$, et al. Top 100 cited articles on rheumatoid arthritis: A bibliometric analysis. Medicine (Baltimore). 2019 Feb;98(8):e14523.

14. Berlinberg A, Bilal J, Riaz IB, Kurtzman DJB. The 100 top-cited publications in psoriatic arthritis: a bibliometric analysis. Int J Dermatol. 2019;58:1023-34

15. Buyukcoban S, Oner O, Hanci V. A bibliometric analysis of the most cited articles in Geriatric Anesthesia. Turkish Journal of Geriatrics 2020; 23: 410-8.

16. Akyol A, Kocyigit BF. Ankylosing spondylitis rehabilitation publications and the global productivity: a Web of Science-based bibliometric 
analysis (2000-2019) Rheumatol Int. 2021;10.1007/s00296-021-04836-0.

17. Bagcier F, Yurdakul OV, Ozduran E. Top 100 cited articles on ankylosing spondylitis. Reumatismo. 2021;72:218-27.

18. Kwan YH, Chua CJ, Kian JXL, Fong W. Top 100 cited articles in the field of rheumatology. Eur $\mathrm{J}$ Rheumatol. 2017 Dec;4(4):294-304.

19. Şenel E, Demir E, Alkan RM. Bibliometric analysis on global Behçet disease publications during 1980-2014: is there a Silk Road in the literature? J Eur Acad Dermatol Venereol. 2017 Mar;31(3):518-522.

20. Oner O, Hanci V. Bibliometric Analysis of the 100 Most Cited Articles on Covid-19 in the Intensive Care Field. J Basic Clin Health Sci 2021; 3: 5165. 